\title{
Questioning LibQUAL+: Critiquing its Assessment of Academic Library Effectiveness
}

\section{Bill Edgar}

School of Information Resources and Library Science, Tucson, Arizona, 85719 bedgar@u.arizona.edu

Advertised as a total market survey of an academic library's users, LibQUAL+ has risen to prominence in recent years as a means of assessing academic library effectiveness. In light of this, this conceptual paper raises and addresses four questions arising from its survey instrument. Doing so reveals that LibQUAL+ only partially conceptualizes a library's operations. Furthermore, it emphasizes users' eventual outcomes, such as improved grades, but does not explicitly conceptualize users' more immediate need for epistemological value in the form of information, education, or persuasion. Finally, LibQUAL+'s survey correctly emphasizes the role of user self-reliance and satisfaction, but it unduly deemphasizes users' need for professional information assistance and their actual experience of quality library service.

Introduction 
Emerging in recent years from the Association of Research Libraries' New Measures Initiative, LibQUAL+, advertised as a 'total market survey' of a library's users, has risen to prominence as a means of evaluating libraries, particularly academic ones. According to LibQUAL+'s World Wide Web site (), over 500 libraries have participated in LibQUAL+. They include ones from colleges and universities, community colleges, as well as academic health sciences and law libraries.

However, in light of its success certain questions, or issues, must be raised concerning LibQUAL+'s ability to determine academic library effectiveness. These arise from LIBQUAL+ itself as well as from any attempt to evaluate libraries. Answering them reveals strengths-and some weaknesses-inherent in LIBQUAL+.

This conceptual paper addresses four questions arising from LibQUAL+'s survey instrument.

My hope is that this paper will encourage the general discussion and practice of evaluating libraries The current version of LibQUAL represents a solid contribution to this endeavor but much more remains to be done.

\section{ServQUAL/LibQUAL+}

LibQUAL+ is conceptually based upon SERVQUAL, a controversial but widely-used generic instrument that measures service quality, primarily in business organizations (Asubonteng, Mcleary \& Swan 1996; Cullen 2001; Hernon \& Nitecki 2001; Kilbourne et. al. 2005; Lassar, Manolis \& Winsor 2000; Palmer \& O’Neil 2003; Sureshchandar et. al. 2002). Moreover, as it has been developed, LibQUAL+ has been discussed in an extensive literature of its own (Cook \& Heath 2001; Cook, Heath, \& Thompson 2002; Cook, Heath, \& Thompson 2003; Cook et. al., 2001, LibQUAL+ Service Quality; Cook et. al., 2001, Search for New Measures; Cook \& Thompson 2000, Higher Order; Cook \& Thompson 2001; Cook \& Thompson, 2000, Reliability and Validity; Heath et. .al., 2002 Heath, Kyrillidou, \& Askew 2004; Hiller 2001; Lincoln 2002; Thompson, Cook, \& Heath 2001; Thompson, Cook, \& Heath 2003, Structure of Perceptions; Thompson, Cook, \& Heath 2003, Two Short Forms; Thompson, Cook, \& Kyrillidou 20005; Thomson, Cook \& Thompson 2002; Wei, Thompson \& Cook 2005).

"In the SERVQUAL model, quality is defined as 'perceived quality' rather than 'objective quality,' that it is dependent on the customer's perception of what they can expect from a service and what they believe they have received, rather than any objective standard as 
determined by professional group or in conventional performance measurement" (Cullen, 2001, p. 664). SERVQUAL actually determines service quality by surveying a service's customers as to their perceptions of the service's quality. Similarly, LibQUAL+'s research approach is to survey four categories of library users-undergraduates, graduate students, faculty, and library staff-as to their perceptions regarding service delivery to users by a specific library. For each survey question "gap scores are calculated between minimum and perceived expectations and desired and perceived expectations. The zone of tolerance is the difference between the minimum and desired scores. Optimally, perceived performance assessments should fall comfortably within that zone" (Cook, et. al. 2001,

Search for New Measures, p. 106). Ideally "constituents perceptions of service delivery are to float between minimum expectations and the desired or optimum level of service. To score below minimum levels is to fall outside the zone of tolerance and to risk erosion of user confidence and support" (Cook, Heath, \& Thompson 2002, p. 22).

Rather than using it to survey users, in this paper I used the 2005 LibQUAL+ survey instrument to critique LibQUAL+ itself (Association of College \& Research Libraries 2005). Considerably smaller than earlier versions, the 2005 survey uses "22 items and a box" to raise questions and record user comments related to Library as a Place, the Affect of Service, and Information Control. The 2005 instrument also allows libraries to add up to five other questions reflecting local library concerns; it contains five questions covering general information literacy outcomes; and it contains three questions covering general satisfaction with library service. The survey I used was conducted for the libraries at Duke University. It is presented in Appendix 1.

\section{Functional/Technical Model of Service Effectiveness}

The dimensions used in the 2005 LibQUAL+ survey's twenty two core questions cover users' experience of service delivery: its emotional impact (affect) on them, the extent to which service delivery is under users' control, and the extent to which a library place comfortable for research and learning is provided. However, a broader, more inclusive approach for determining service quality, one advocated in this paper, is what Lassar et. al. (2000), drawing upon earlier work by Gronroos (1983), call the "Functional/Technical Model of Quality" (p. 246). They argue that "technical quality involves what is provided, and functional quality considers how it is provided. Examples of technical quality might include the quality and effectiveness of diagnosis and medical procedures at a hospital, the effectiveness of car repair, or the cleanliness of a room at a hotel. Functional quality, on the other hand, comprises the care and/or manners of the personnel involved in the delivery of service products" (pp. 246-247). 
I propose that these two models can complement one another, creating a balance between emphasizing user perceptions of service delivery, i.e. how it is provided, and the essence, the "what," of the service itself. If delivery is not done well, then consumers will often act on their perceptions to abandon the service quickly, even if the service's essence is there. But if the essence of the service is not there, then consumers will gradually perceive this underlying reality and abandon the service anyway, even if its delivery is done well.

\section{Determining Library Effectiveness}

LibQUAL+'s focus upon service delivery emphasizes the Functional model of quality. In contrast, rather than presenting empirical data analyzing a specific library's delivery of library service, this conceptual paper primarily addresses some issues inherent to developing the Technical side of a model for academic library effectiveness. It does so by raising and answering four questions arising from LIBQUAL+s instrument. From this discussion, the paper concludes with a brief assessment of the survey's approach to determining academic library effectiveness. My hope is that this discussion and assessment can contribute to future revisions of LibQUAL+, as well as of other methods of library evaluation.

\section{LIQUAL+ Survey Instrument: Library as a Place}

Question 1: How do libraries operate to serve their users?

\section{Professional Activities and Results}

Answering this question requires developing a conceptualization of the internal operations of libraries. Doing so reveals that while a library is a place, as LIBQUAL+ indicates, it is also much more.

Several theoreticians have proposed such conceptualizations (Atkinson 1996; Baker \& Lancaster 1993; McGrath 2002). Baker and Lancaster (1993) delineate library functions to include selection, acquisition, cataloging, indexing, and physical preparation of content items (p. 10). However, perhaps the most straightforward is one suggested by Atkinson (1996). He proposes that information access is provided through a process of professional activities in which librarians select items of content, such as a monograph or scholarly journal; organize (classify) them; create descriptions (representations) of them; acquire 
formal legal control over them; and manage in some way the place at which the content items are to reside (pp. 244-245).

These activities create results. Selection creates collections of content; organization develops content classification schemes, such as the Library of Congress system, into which collections are categorized; and description creates sets of content representations, such as catalogs. Acquisition of items enables legal control, such as ownership, over them. Place management develops the place, a physical building or a computing environment, in which content is made available to users (Atkinson, 1996, pp. 244-245). Therefore, a library is not only a place-it is also collections, patterns into which they are organized, descriptions of their items, and legal control over them.

\section{Three General Forms of Access}

This process occurs across academic libraries as collections are developed, enabling three kinds of access. Collections, classification schemes, and item descriptions create consistent intellectual access to content items. Ideally, similar items, such as monographs and journals covering the same subject, are selected with the goals of including all monographs and journals that share the similarity while excluding those that do not. Thus, the point of selection is not to provide a "comprehensive," all-encompassing collection but, instead, to provide one that is definitively narrowed from the entire bibliographic universe.

Once this occurs, the collection's items are classified into similar categories, normally using Library of Congress or Dewey Classification Numbers, creating an organizational pattern for the items similar to one used in the library's other collections. Then, the items are given similar labels: all the monographs and journals are labeled as such, normally using Library of Congress Subject Headings. Used together, collections, classification schemes, and item descriptions create intellectual similarity within collections, enabling the user to find content items without having to search through the entire bibliographic universe.

The body of legal control-ownership, lease, or borrowing-over a library collection creates dependable legal access to content items. Though their legal control, collection items are made available at specific times without users having to do the necessary work of purchase, rental, or borrowing on their own.

The library place for a collection creates rapid physical access to content items. Though a building or computing environment, collection items are made available in specified places without users having to look throughout the world for the content they need. It is 
the consistent intellectual, dependable legal, and rapid physical access to content, created by the results of librarianship activities, that is the essence of library service, making a library not only a place, as LibQUAL recognizes, but also intellectual similarity within its collections and a body of legal control over them (Atkinson, 1996, p. 244-245).

\section{Three General User Needs}

Furthermore, these three forms of access delineate groups of users of any given library along three dimensions of need. When utilized, consistent intellectual access meets users' need for limiting of the bibliographic universe according to some form of similarity, e.g. by subject. This need reflects some commonality, e.g. interest in the same topic, which narrows the group of users.

When utilized, dependable legal access meets the narrower user group's need for access to content items across time. This time can vary from a few weeks to many decades. This means that a library's users, whatever their point of intellectual similarity, exist not only now but to some point in the future. Therefore, in contrast to LibQUAL's advertisement, the total body, or "market," of academic library users often cannot be comprehensively surveyed at one point in time, since some of these users, who will utilize the library in the far future, might not even be living yet. Materials these future users could need might need to be selected, organized, described, acquired, and put into a place now if they are to be available then.

Traditionally relatively insolated from immediate financial pressures, academic libraries have been exceptionally effective at serving users of the far future. Yet they now face the reality that many current users do not value this, so that these libraries must find other, more immediate measures of their contribution, such as grants, recognition of their standing through library rankings, or positive perceptions of service delivery.

When utilized, rapid physical access meets the narrower user group's need for access to content items within a place. This can vary from the physical building in which selection, organization, description, and acquisition of legal control were done to a computing environment on the other side of the world. Therefore, the total body of library users sometimes cannot be comprehensively surveyed at one point in space, since some of these users, who utilize the library in a distant space, are might not be physically available to be surveyed. The academic library, traditionally relatively free from the pressure to make a profit, can often bear the expense of serving these distant users well. This progression of librarianship activities to user needs is summarized in Figure 1: 
When utilized, rapid physical access meets the narrower user group's need for access to content items within a place. This can vary from the physical building in which selection, organization, description, and acquisition of legal control were done to a computing environment on the other side of the world. Therefore, the total body of library users sometimes cannot be comprehensively surveyed at one point in space, since some of these users, who utilize the library in a distant space, are might not be physically available to be surveyed. The academic library, traditionally relatively free from the pressure to make a profit, can often bear the expense of serving these distant users well. This progression of librarianship activities to user needs is summarized in Figure 1:

Figure 1: Internal library operations and user needs

\begin{tabular}{|c|c|c|c|}
\hline Activity & Result & General Access & General User Need \\
\hline Selection & Collections & \multirow{3}{*}{$\begin{array}{l}\text { Consistent } \\
\text { intellectual }\end{array}$} & \multirow{3}{*}{$\begin{array}{l}\text { Intellectual similarity within } \\
\text { collections }\end{array}$} \\
\hline Organization & Classification pattern & & \\
\hline Representation & Item descriptions & & \\
\hline Acquisition & Legal control & Dependable legal & Time of access \\
\hline $\begin{array}{c}\text { Place } \\
\text { Management }\end{array}$ & $\begin{array}{c}\text { Building or computing } \\
\text { environment }\end{array}$ & Rapid physical & Place of access \\
\hline
\end{tabular}

\section{LibQUAL+ and General User Needs}

The 2005 LibQUAL+ instrument does indirectly address the user need for similarity within collections (Figure 1, top rows). It did this by asking the users whether the library provided print materials or electronic journals they need for their intellectual work (Appendix 1: IC 3, IC 8). Other demographic questions in LibQUAL+ do ask students and faculty their disciplinary affiliation, so that respondents' answers to these items can be cross-tabulated. However, the 2005 instrument does not examine extensively how, when utilized, consistent intellectual access provided by a library collections, classification patterns, and item descriptions creates the intellectual similarity within collections necessary for users' work.

Also, in its 2005 survey, LIBQUAL+ does superficially address how, when utilized, dependable legal access provided by library legal control of content makes materials available at times required by users (Figure 1, middle row). It does so with its localized question as to "convenient service hours." However, examining this more extensively would provide a useful tool to shown not only the immediate value to users provided by the academic library but also its more cumulative intellectual contribution to them over 
time.

LIBQUAL+'s 2005 instrument (LP 1-5) does indicate users' need for a library place (Figure 1 , bottom row), focusing upon users' experience of the library as a comfortable, quiet space for studying, learning, and research. Without question, the library as a place for learning, group work, and even peace and quiet is important.

However, with its one question covering "efficient interlibrary loan/document delivery," LibQUAL+ does not reveal extensively how, when utilized, rapid physical access provided by the library' building and computing environment makes materials available at places required by users. Examining more extensively the user need for content items to be available within a specified place is critical, since this virtual environment or physical structure is what distinguishes the library from other possible places to study on campus, such as offices or unused classrooms.

Question 2: What is the value provided to library users?

These three types of general user information needs-collection similarity, access across time, and access within specified places-are met as library users search for, retrieve, and use content items, once they have been selected, organized, described, acquired, and put into a place. This use occurs as library users read, view, or listen to content items held by the library.

As this happens, library users receive epistemological outcomes, i.e. some intellectual value from library service. Various attempts have been made to identify or define these intellectual outcomes (de Jager 2002; Ford 1989; Ford 2002; Hernon \& Nitecki 2001; Kyrillidou 2002; Lane 2002; Revil 1990; Thompson, Cook, \& Kyrillidou 2005). For example, Ford (2002) proposed this could be satisfied researchers for an academic library or greater literacy for a public library. De Jager (2002) suggested improved academic achievement in the form of grades. Furthermore, the 2005 LibQUAL instrument (Thompson 2005) does attempt to isolate epistemological outcomes related to improvement in information literacy. These include a user's improvement in discerning trustworthy information, advancement in his/her discipline, or greater ability to stay current in his or her field (p. 518).

An alternative, more precise approach used here (Lane 2002, p. 140) proposes that these outcomes of content exposure consist first of intellectual change of some kind for the library user. These changes in turn provide the basis for the subsequent intellectual outcomes LibQUAL+ emphasizes, such as improved grades, greater literacy, or advancement within a discipline. 
This intellectual change can occur in several forms as phenomena within a user's mental state are altered by exposure to content held by a library. It could be informing, meaning changing a library user's understanding of reality exists at one point in time. Second, intellectual change could be education, meaning changing the user's understandings of how reality exists across multiple points in time or the person's skills resulting from these understandings. For example, an M.B.A. student might read a monograph held by an academic library so that she becomes more educated in the skill of financial planning, thereby improving her grade in a finance course. Third, intellectual change could be persuasion, meaning changing the user's beliefs and attitudes about how reality exists at one or multiple points in time. For instance, an English faculty member might develop a new school of literary thought after reading essays on literary theory held by a university library, leading to recognition within his academic discipline.

These changes in understandings, skills, beliefs, and attitudes can be conceptualized and measured using concepts from philosophy, education, and psychology. Focusing upon these immediately influenced mental phenomena will support the development of theory predicting the influence of academic library service upon what LibQUAL+ currently emphasizes: users' eventual outcomes related to their educational programs or careers.

\section{LIBQUAL+ Survey Instrument: Information Control}

Question 3: Are library users able to be self-reliant?

Emphasizing users' experiences of content search and retrieval, LibQUAL+'s 2005 instrument indicates that they can be. Its core questions on Information Control (Appendix 1: IC 1-8) (as well as a locally developed question used at Duke University) ask whether library enables users to locate print or electronic information on their own, at their home or office, so that they can work independently. Together, they reflect a strong desire among library users to control their own information search, retrieval, and use. One pattern revealed in the LibQUAL+ literature (Cook \& Heath 2001) is that library users prefer to be self-reliant, relying upon bibliographic instruction and, to a greater degree, interactions with librarians to gain necessary information seeking and retrieval skills (pp. 555-556). The dominant pattern is one of sporadic, as-needed user-librarian contact. "Albeit inefficient, independent trial and effort is, indeed, the most commonly followed strategy to building self-confident user behavior" (p. 553).

A better answer to this question is: It depends on the user, who, as she performs search and retrieval, needs to understand the often complex intellectual similarity within the particular collection being accessed, legal control acquired over it, and place in which it is 
available. Given that their focus is usually upon their subject content, are users able to understand this at the necessary depth in an on-going way?

I argue that while some users can, many cannot, so that the pattern of independent trial and effort is frequently inadequate. Users often do need much more help to search and retrieve content than they receive. This is particularly true of undergraduates throughout their educational programs and of graduate students early in their programs, before their understanding of their topic and its information resources grows. They are students. By definition, they do not know and so are learning their topic-and how library service provides access to its information resources.

For example, a collection of full-text biology journals in botany might be leased by an academic library and be made available to users' desktops with extensive search capability. Here the narrowing is by topic; the legal control is rental; and the place is a computing environment with extensive nuances as to information retrieval. An undergraduate taking botany as an elective often would not be knowledgeable as to similarity of the library's collections, legal control of the items, and the place in which items are available. This ignorance can severely limit the user's independent search and retrieval and so lessen the extent to which the user receives intellectual value from using content.

For example, a collection of full-text biology journals in botany might be leased by an academic library and be made available to users' desktops with extensive search capability. Here the narrowing is by topic; the legal control is rental; and the place is a computing environment with extensive nuances as to information retrieval. An undergraduate taking botany as an elective often would not be knowledgeable as to similarity of the library's collections, legal control of the items, and the place in which items are available. This ignorance can severely limit the user's independent search and retrieval and so lessen the extent to which the user receives intellectual value from using content.

\section{LIBQUAL+ Survey Instrument: Affect of Service}

Question 4: Are library users who are satisfied with library service delivery likely to be ones who are well served by the service's underlying essence?

LibQUAL+'s instrument indicates that they usually are, or it ignores the issue entirely. LibQUAL+'s 2005 core questions on the Affect of Service (Appendix 1: AS 1-9) focus upon the emotional, interpersonal, and intellectual experience of library service delivery. They ask if the library offers knowledgeable employees, a willingness to help users, courteous 
assistance, and reliable individual attention. Together their emphasis is upon users' satisfaction with delivery of the latter stages of library service: information search and retrieval.

The more accurate answer to this question is: Not always. User satisfaction depends upon the knowledge of the user as to the service's underlying essence, but it is also influenced by the nature of the intellectual value received by library users. A knowledgeable user-one aware of the similarity within the library collections, the legal control of collection items, and the place at which collection items reside-might be both well served and satisfied. However, this may not be true of an less knowledgeable user, such as an undergraduate. In this case the student's limited awareness of collection similarity, legal control, and place might make him happy with what he is able to retrieve on his own, even if it is far from what would provide him with excellent educational intellectual value. Here the user has received poor service, though he is happy with its delivery. Often, undergraduates come close to this situation by being very satisfied with service that, while not bad, is only adequate.

Also, since providing intellectual value is done through the difficult work of creating intellectual, legal, and physical access, realizing this value by utilizing this access can also be arduous. While an experienced library user is likely to understand this difficulty, an inexperienced one such as undergraduate might not. In this case a librarian might help an undergraduate perform information search and retrieval, so that the student receives excellent material for an assignment but is still unhappy with the difficulty of the work necessary to retrieve these items. Here, though the user has received good service, he is highly unsatisfied with its delivery.

\section{Evaluation of LibQUAL}

As discussed above, LibQUAL+'s survey instrument emphasizes the Functional element of library service, primarily users' experience of the service's delivery. In contrast, using the Technical element of library service, I propose that assessing an academic library's effectiveness must be based upon isolating the immediate epistemological value it provides its users through its internal professional activities, their results, and the forms of access these results provide. Consistent intellectual access-based upon a narrowed, intellectual similarity within library collections-means that these epistemological outcomes are created for an actual user group that is a subset of potential user groups. Dependable legal access-based upon a body of legal control over collections-means that these smaller user groups will realize this value by interacting with the library at specific points across time. Rapid physical access-based upon a library place at which collections 
are located-means that these actual groups will realize these outcomes by interacting with the library place.

For users, this value is created as they act-with different degrees of self-reliance-on their differing perceptions of collection similarity, content legal control, and library place to search for, retrieve, and use items in library collections. As they do so, they experience differing levels of satisfaction with the quality of service provided to them.

Any attempt to determine library effectiveness, such as LIBQUAL, must capture this reality of intellectual value realized and perceived at different levels of self-reliance and satisfaction. LIBQUAL achieves some of this but leaves much undone. LIBQUAL+'s survey instrument focuses primarily upon one of the three dimensions of library operations-the library place-but not the other two, intellectual similarity and times of access. In doing so, the survey only partially conceptualizes a library's operations. Furthermore, while it does recognize users' eventual epistemological outcomes, e.g. improved grades, it does not explicitly conceptualize users' need for immediate epistemological value in the form of information, education, or persuasion. Finally, LibQUAL+'s survey correctly emphasizes the role of user self-reliance and satisfaction, but it unduly deemphasizes the users' need for professional assistance and their actual experience of quality library service.

\section{Conclusion}

To determine library effectiveness, there are other methodologies that could be employed in addition to LibQUAL+'s user survey, including interviews, observation, content analysis, and the analysis of existing statistics. No one method can address all the issues raised by the questions discussed in the paper. Used together, these could examine library users' satisfaction and underlying experience with the library along all three of its operational dimensions-intellectual similarity, time, and place-at varying levels of user self-reliance.

Gradually, through collaborative effort, what can emerge is a framework for understanding the relationships among an academic library's professional activities and their results; its three general forms of information access; its users' three general information needs; the immediate epistemological value provided to users; along with its users' satisfaction and self reliance concerning library service delivery. The result will allow academic libraries to demonstrate immediate effectiveness where appropriate but also support them in showing their long-term contributions. This cumulative effectiveness is vital but difficult to determine. Doing so will require sustained, extensive effort, not only by the academic library community, but also by other scholarly disciplines, such as philosophy, psychology, and education. 


\section{References}

Association of Research Libraries (2005) LibQUAL+ Spring 2005 Survey: Duke University http://www.lib.duke.edu/libqual/Washington D.C.: Association of Research Libraries

Association of Research Libraries (2005) LibQUAL+ World Wide Web site http://www.libqual.org

Asubonteng, P., McCleary, K.J., \& Swan, J. (1996) ServQUAL revisited: A critical review of service quality Journal of Services Marketing 10(6), 62-81

Atkinson, R. (1996) Library functions, scholarly communication and the foundation of the digital library: Laying claim to the control zone Library Quarterly 66, 239-65

Baker, S.L. \& Lancaster, F.W. (1993) The Measurement and Evaluation of Library Services Arlington, VA: Information Resources Press

Cook, C. \& Heath, F. (2001) Users' perceptions of library service quality: A LibQUAL+ qualitative study Library Trends 49(4), 548-584

Cook, Heath, F. \& Thompson, B. (2002) Score norms for improving library service quality: A LibQUAL+ study Portal: Libraries and the Academy 2(1) 13-26

Cook, C., Heath, F., \& Thompson, B. (2003) 'Zones of tolerance' in perceptions of library service quality: A LibQUAL+ study Portal: Libraries and the Academy 3(1), 113-123

Cook, C., Heath, F., Thompson, B. \& R. Thompson. (2001) LibQUAL++: Service quality assessment in research libraries IFLA Journal 4, 265-268

Cook, C., Heath, F., Thompson, B. \& R. Thompson. (2001) The search for new measures: The ARL LibQUAL+ Project-A preliminary report Portal: Libraries and the Academy 1(1), 103-112

Cook, C. \& Thompson, B. (2000) Higher order factor analytic perspectives on users' perceptions of library service quality Library \& Information Science Research 22(4), 292-404

Cook, C. \& Thompson, B. (2001) Psychometric properties of scores from the Web-based LibQUAL+ study of perceptions of library service quality Library Trends 49(4), 585-604

Cook, C. \& Thompson, B. (2000) Reliability and validity of SERVQUAL scores used to evaluate perceptions of library service quality Journal of Academic Librarianship 26(4), 248-258

Cullen, R. (2001) Perspectives on user satisfaction surveys Library Trends 49(4), 
De Jager, K. (2002) Impacts and outcomes: Searching for the most elusive indicators of academic library performance In J. Stein, M. Kyrillidou, \& D. Davis, Eds. Meaningful Measures for Emerging Realities: Proceedings of the 4th Northumbria International Conference on Performance Measurement in Libraries and Information Services 291-297. Washington, D.C.: Association of Research Libraries

Ford, G. (1989) Approaches to performance measurement: Some observations on principles and practice British Journal of Academic Librarianship 4 (2), 74-87

Ford, G. (2002) Strategic uses of evaluation and performance measurement In J. Stein, M. Kyrillidou, \& D. Davis (Eds.) Meaningful Measures for Emerging Realities: Proceedings of the 4th Northumbria International Conference on Performance Measurement in Libraries and Information Services 19-30 Washington, D.C.: Association of Research Libraries

Gronroos, C. (1983) Strategic Management and Marketing in the Service Sector (report 83-104), Cambridge, MA: Marketing Sciences Institute.

Heath, F., Cook, C., Kyrillidou, M. \& Thompson, B. (2002) ARL index and other validity correlates of LibQUAL+ scores Portal: Libraries and the Academy 2(1), 27-42

Heath, F.M., Kyrillidou, M., \& Askew, A. (2004) Libraries Act on their LibQUAL+ Findings: From Data to Action Journal of Library Administration 40(3/4)

Hernon P. \& Nitecki, D. (2001) Service quality: A concept not fully explored Library Trends 49(4), 687-708

Hiller, S. (2001) Assessing user needs, satisfaction, and library performance at the University of Washington Libraries Library Trends 49(4), 605-625

Kilbourne, W. E., Duffy, J.A., Duffy, M., \& Giarchi, G. (2005) The applicability of SERVQUAL in cross-national measurements of health-care quality Journal of Services Marketing 18(6/7)

Kyrillidou, M. (2002) From input and output measures to quality and outcome measures, or, from the user in the life of the library to the library in the life of the user Journal of Academic Librarianship 28(1), $42-46$

Lane, G. (2002) Developing outcome-based indicators: Resource's learning and access standard In J. Stein, M. Kyrillidou, \& D. Davis Meaningful Measures for Emerging Realities: Proceedings of the 4th Northumbria International Conference on Performance Measurement in Libraries and Information Services 137-143. Washington, D.C.: Association of Research Libraries 
Lassar, W.M., Manolis, C., Winsor, R.D. (2000) Service quality perspectives and satisfaction in private banking Journal of Services Marketing 18(3), 244-274

Lincoln, Y.S. (2002) Insights into library services and users from qualitative research Library and Information Science Research 24, 4-16

McGrath, .W.E. (2002) Explanation and prediction: Building a unified theory of librarianship, concept and review Library Trends 50 (3), 350-370

Palmer, A. \& O'Neil, M. (2003) The effects of perceptual processes on the measurement of service quality The Journal of Services Marketing 17(2/3), 254-271

Revill, D.H. (1990) Performance measures for academic libraries Encyclopedia of Library and Information Science 294-332. New York: M. Dekker

Sureshchandar, G.S., Rajendran, C., \& Anantharaman, R.N. (2002) Determinants of customer-perceived service quality: A confirmatory factor analysis approach Journal of Services Marketing 16(1), 9-34

Thompson, B., Cook C., \& Heath, F. (2001) How many dimensions does it take to measure users' perceptions of libraries: A LibQUAL++ study Portal: Libraries and the Academy 1(2), 129-138

Thompson, B., Cook, C. \& Heath, F. (2003) Structure of perceptions of service quality in libraries: A LibQUAL++ study Structural Equation Modeling 10(3), 456-464

Thompson, B., Cook, C. \& Heath, F. (2003) Two short forms of the LibQUAL++ survey: Assessing users' perceptions of library service quality Library Quarterly 73(4), 453-465

Thompson, B., Cook C., \& Kyrillidou, M. (2005) Concurrent validity of LibQUAL++ scores: What do LibQUAL++ scores measure? Journal of Academic Librarianship 31(6), 517-522

Thompson, B. Cook C., \& Thompson, B. (2002) Reliability \& structure of LibQUAL++ scores: Measuring perceived service quality Portal: Libraries and the Academy 2(3), 3-12

Wei, Y., Thompson, B. \& Cook, C. (2005) Scaling users' perceptions of library service quality using item response theory: A LibQUAL++ study Portal: Libraries and the Academy 5(1), 93-104

\section{Appendix I}

LibQUAL+ 2005 Survey Instrument Questions (Duke University) Core Questions: Affect of Service

AS-1 Employees who instill confidence in users

AS-2 Giving users individual attention 
AS-3 Employees who are consistently courteous

AS-4 Readiness to respond to users' questions

AS-5 Employees who have knowledge to answer questions

AS-6 Employees who deal with users in a caring fashion

AS-7 Employees who understand the needs of their users

AS-8 Willingness to help users

AS-9 Dependability in handling users' service problems

\section{Core Questions: Information Control}

IC-1 Making electronic resource accessible from my home or office

IC-2 A library Web site enabling me to locate information on my own

IC-3 The printed library materials I need for my work

IC-4 The electronic information resources I need

IC-5 Modern equipment that lets me easily access needed information

IC-6 Easy-to-use access tools that allow me to find things on my own

IC-7 Making information easily accessible for independent use

IC-8 Print and/or electronic journal collections I require for my work

Core Questions: Library as a Place

LP-1 Library space that inspires study and learning

LP-2 Quiet space for individual attention

LP-3 A comfortable and inviting location

LP-4 A getaway for study, learning or research

LP-5 Community space for group learning and group study

\section{General Satisfaction Questions}

-In general, I am satisfied with the way in which I am treated at the library. 
-In general, I am satisfied with library support for my learning, research, and/or teaching needs.

-How would you rate the overall quality of the service provided by the library?

\section{Information Literacy Outcomes Questions}

-The library helps me stay abreast of developments in my field(s) of interest.

-The library aids my advancement in my discipline.

-The library enables me to be more efficient in my academic pursuits.

-The library helps me distinguish between trustworthy and untrustworthy information.

-The library provides me with the information skills I need in my work or study

\section{Local Questions Summary}

-Library keeping me informed about all of its services

-Teaching me how to locate, evaluate, and use information

-Efficient interlibrary loan/document delivery

-Convenient service hours

-Providing services as promised 